ACTA THERIOLOGICA

Vol. $32,28: 463-474,1987$

\title{
Skull Variability of Talpa romana stankovici from Macedonia
}

\author{
Boris KRYŠTUFEK
}

Kryštufek B., 1987: Skull variability of Talpa romana stankovici from Macedonia. Acta theriol., 32, 28: 463-474 [With 3 Tables \& 4 Figs.]

The skulls of 46 Talpa romana stankovici V. et E. Martino, 1931 from Macedonia were examined. Considerable differences were found between the sexes. Males are larger in all cranial dimensions with the exception of interorbital constriction, and have higher values of the coefficients of variation. The size of $T$. romana stankovici does not depend on the altitude. Differences between three population groups were found in four out of five analysed cranial measurements. Differences between the geographic populations are more important than those between zones of altitude.

[Natural History Museum of Slovenia, Prešernova 20 - p.p. 290, 61001 Ljubljana, Yugoslavia].

\section{INTRODUCTION}

Talpa romana stankovici V. et E. Martino, 1931 (T.r.s.) is an endemic relict mole from the Balcan Peninsula. Its closest allies live in southern Italy and probably. in the Caucasus (Corbet, 1978; Gureev, 1979; Gromov \& Baranova, 1981). The studies of T.r.s. have been devoted so far to its distribution and taxonomic status, above all its relationship to Talpa europaea (Todorović, 1967; Petrov, 1971, 1974) and Talpa romana (Capanna, 1981). Within this framework its skull variability was also studied.

Open taxonomic questions concerning T.r.s. and its relationships to some other populations of Talpa cf. romana from the Balcan Peninsula, as well as to Talpa romana from Italy necessitate a closer knowledge on its skull variability. The aim of the present study is to describe the skull of T.r.s. from western Macedonia where the description of that taxon originates from.

\section{MATERIAL AND METHODS}

Fourty-six specimens of T.r.s. were examined from the entire territory of western Macedonia. The majority of the material used in this study is kept in the collection of B. Petrov (Belgrade), and the rest in the Natural History Museum of Slovenia (Ljubljana). In determining the material at the species level I followed the characters presented by Petrov (1971).

The following dimensions were measured on freshly caught animals: (1) W - 
weight (in grams), (2) HB - head and body length (from the snout to the anus), (3) $\mathrm{TL}-$ tail length (from the anus to the tail tip), (4) $\mathrm{HF}-$ hind foot length (without claws).

Ten linear measurements were taken on each of the skulls using a vernier caliper with accuracy to the nearest $0.1 \mathrm{~mm}$. Their definitions and symbols are as follows: (1) $\mathrm{CB}$ - condylobasal length, (2) GL - greatest length of skull, (3) ZY - zygomatic breadth, (4) IC - interorbital constriction, (5) BB - braincase breadth, (6) $\mathrm{BH}-$ braincase height, (7) RC - rostrum breadth over canins, (8) RM - rostrum breadth over molars, (9) MT - maxillary tooth-row length, (10) MD - mandible length.

The following quotient indices were calculated:

(1) $\mathrm{MT} \times 100: \mathrm{CB}=\mathrm{IND} 1$

(2) $\mathrm{RM} \times 100: \mathrm{CB}=\mathrm{IND} 2$

(3) $\mathrm{RC} \times 100: \mathrm{CB}=\mathrm{IND} 3$

All the skulls were from the adult animals. Due to a limited number of the skulls available the calculations include also damaged skulls on which not all the parameters could be measured. All measurements could be taken on 32 skulls $(=70 \%)$.

Mean values $(\bar{x})$, standard deviations $(S D)$, coefficients of variation $(C V)$ and correlation coefficients $(r)$ were calculated. To present mutual relations and interdependences among particular skull measurements the method of Terentjev's pleiads (Terentjev, 1943; according to Caboń-Raczyńska, 1964; Ruprecht, 1972, 1974, 1984) has been adopted.

\section{RESULTS}

\subsection{Sex Dimorphism}

Greather mean values of body and cranial dimensions were noticed in the males (Table 1). The differences between sexes are significant at $p<.01$ level, with the exception of IC where no sex dimorphism is expressed. Quotient indices reveal no differences between the sexes.

The sex dimorphism was described as quotients of male to female mean values for any of the 14 different measurements and for indices. These quotients were between 1.04 (HF) and 1.21 (W) in body dimensions, and between 1.02 (IC) and $1.04(\mathrm{ZY}, \mathrm{BH}, \mathrm{RC}, \mathrm{RM})$ in skull measurements. The mean dimensions of males are greater than those of females from 2 to $21 \%$. The differences between sexes are larger in the body than the skull measurements.

The coefficient of variation $(\mathrm{CV})$ varies between 1.46 (IND1) and 11.12 (W) in the males, whereas between 1.35 (IND1) and 9.57 (TL) in the females. In 12 dimensions and quotient indices out of totally $14(=85.7 \%)$ males have a higher $C V$ than females. Thus we can say that males reveal a greater variability. The differences become more obvious in metrica] characters than in quotient indices. 


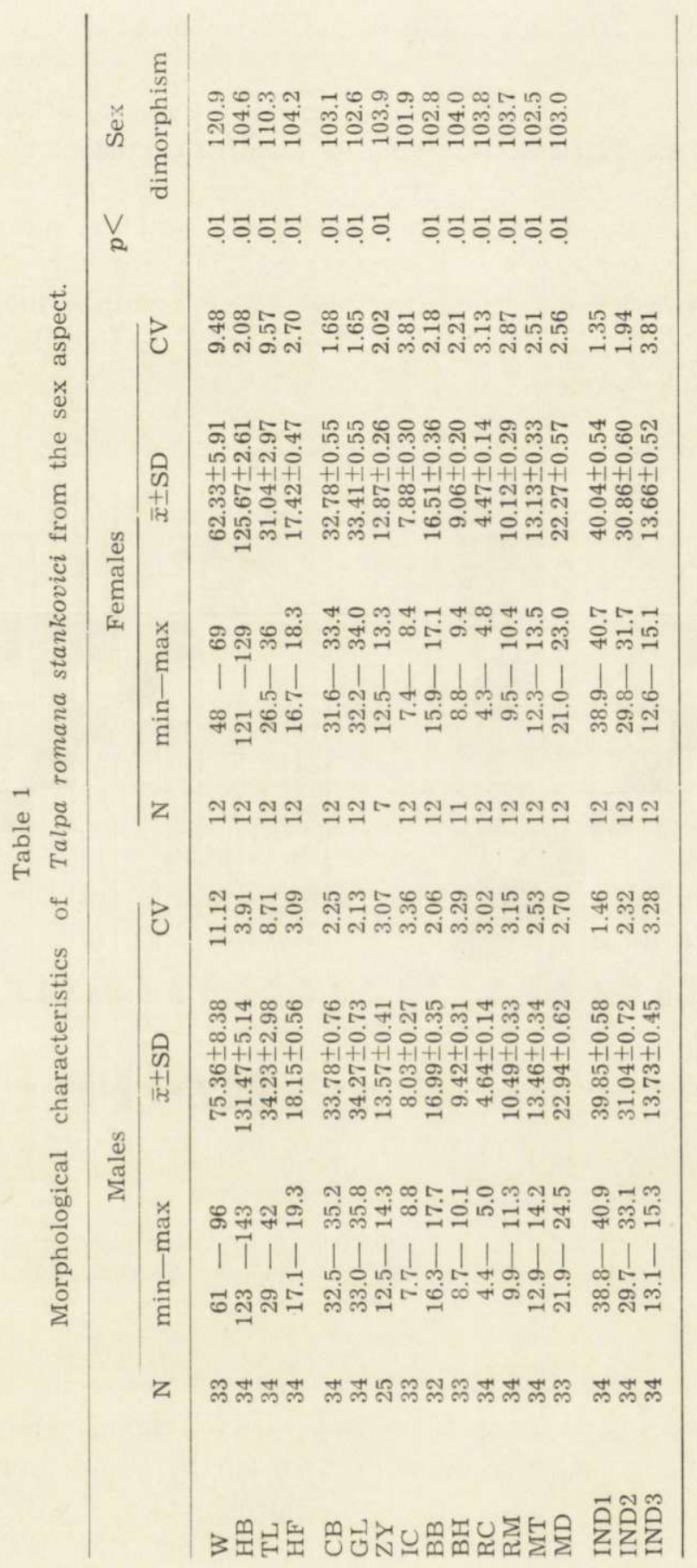




\subsection{Correlation Structure of Skull Dimensions}

In males $37(=82 \%)$ correlation coefficients $(r)$ are significantly greater than zero $(p<.05 ; 32$ of them at $p<.01$ level). In females 17 coefficients $(=38 \%)$ only are significantly greater than zero $(p<.05 ; 14$ i.e. $31 \%$ at $p<.01$ level) which obviously results from a smaller sample. This is evident particularly in ZY where out of 12 females only 7 had undamaged zygomatic arches. Thus, in spite of high values the correlation coefficients of ZY with other skull measurements are significantly greater than zero in two cases only (Fig. 1).

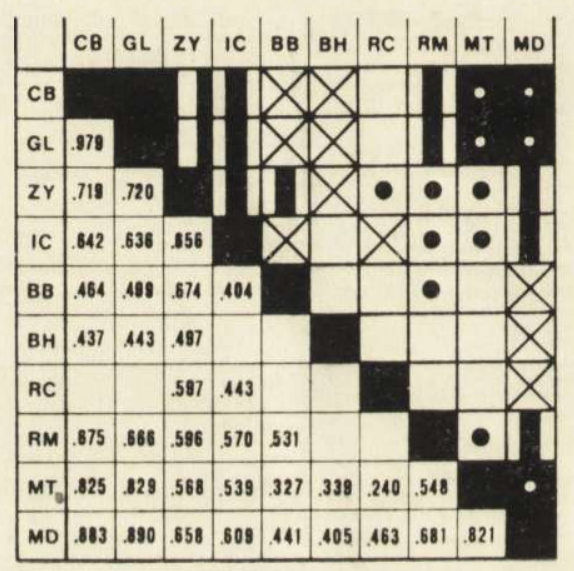

M A L E S

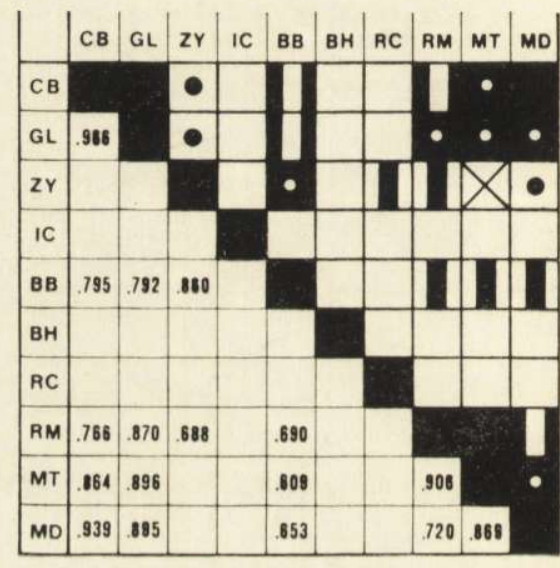

FE M A LES

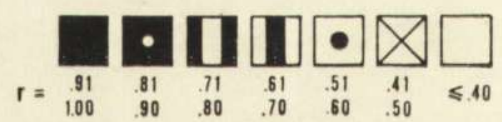

Fig. 1. Correlation structure of skull dimensions in Talpa romana stankovici from the sex aspect. Inscribed are only the coefficients of correlation significant at $p<.05$.

Out of 10 measurements compared, 7 have high values of $r$, the average of which range from 0.517 to 0.660 in males and from 0.538 to 0.600 in females. In males these measurements are: CB, GL, ZY, IC, RM, MT, MD, and in females: CB, GL, ZY, BB, RM, MT, MD. Thus, with the exception of IC and BB 6 measurements in either sex are most closely correlated with one another and the remaining measurements. The 
remaining three dimensions have low $r$ values in males, the average of which range from 0.312 to $0.416(\mathrm{BB}, \mathrm{BH}, \mathrm{RC})$. In females the mean values of correlation coefficients in three measurements (IC, BH, RC) are quite low, nearing zero (range $0.164-0.195$ ).

In both sexes the correlation coefficients show variable range and frequency distribution. In males the range varies between $0.116(\mathrm{BH}-\mathrm{RC})$ and $0.979(\mathrm{CB}-\mathrm{GL})$ and in females between $-0.284(\mathrm{BB}-\mathrm{RC})$ and 0.966 (CB-GL). In males the frequency distribution of $r$-values has three peaks (Fig. 2). Two lower ones include dependent and independent connections, respectively, and the central one "mixed" connections: In females the polarization in the $r$-values frequency is all the more obvious. A part of coefficients are grouped in the range of dependent connections of males, another in the range of independent connections of males and lower, near zero or below it in the range of negative values. The correlation coefficients thus reveal a much greater variability and a larger range in females than in males.

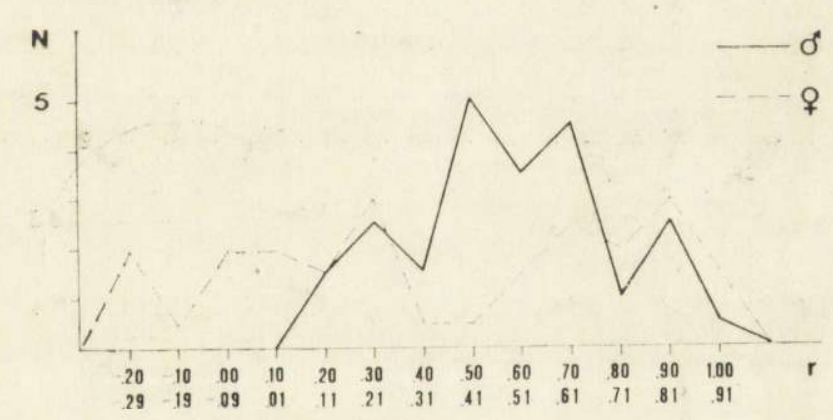

Fig. 2. Distribution of frequencies of correlation coefficients for skull measurements in Talpa romana stankovici from Macedonia from the sex aspect.

In males the group of dependent pleiads relates to the following four measurements: CB, GL, MT, MD. In females this group is extended also to RM. In the latter a small dependent pleiad is formed also by the pair $\mathrm{ZY}-\mathrm{BB}$ (Fig. 3). In males the group of dependent pleiads consists of longitudinal measurements only, whereas those of females include also broadness characters.

In males the group of independent pleiad is formed only by pair $\mathrm{BH}-\mathrm{RC}$ and in females by $\mathrm{BH}-\mathrm{IC}$. In both sexes $\mathrm{BH}$ reveals a very slight connection with other craniological measurements. 
MALES
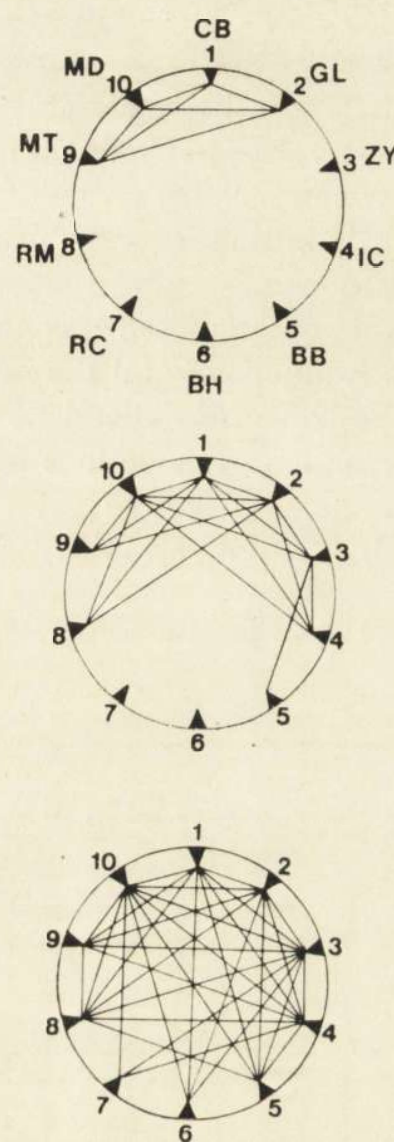

FEMALES

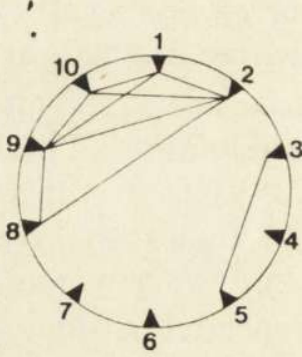

$r \geq 0.8$

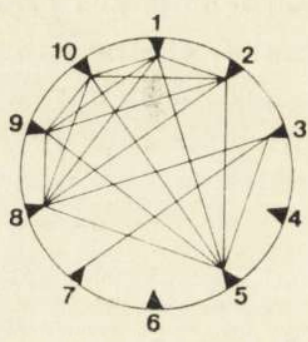

$r \geqslant 0.6$

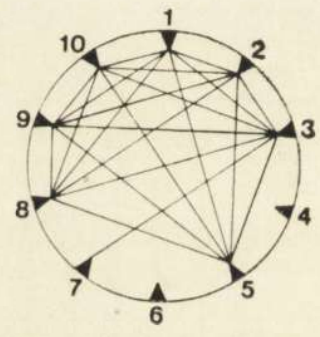

Fig. 3. Correlation structure of skull measurements in Talpa romana stankovici from the sex aspect. The differences between the sexes are presented by means of Terentjev's correlation pleiad method. The circle is devided into ten sections presenting skull measurements denoted by the symbols. Note that the group of dependent pleiads is related to the greater number of females measurements than of males.

\subsection{Interpopulation Variability}

In studying interpopulation variability the work was concentrated on the males only. The females were excluded due to a small number of specimens available. Five measurements were chosen, three of them (CB, MT, MD) forming a strong dependent pleiad. The interpopulation 
variabilities were studied from two points of view: the altitude and the geographic variability.

The material was grouped into three altitudinal zones: (1) 500-1000 $\mathrm{m}$ a.s.l., (2) $1000-1500 \mathrm{~m}$ a.s.l., (3) above $1500 \mathrm{~m}$ a.s.l. The moles living in the zone of 1000 to $1500 \mathrm{~m}$ have smaller BB (braincase breadth) than those of the populations occupying lower as well as higher areas. The other measurements obviously elude the influence of the altitude (Table 2).

\section{Table 2}

Variation in skull measurements in males Talpa romana stankovici from three different zones of altitude (in $\mathrm{m}$ a.s.1.). ${ }^{*} p<.05,{ }^{* *} p<.01$.

\begin{tabular}{|c|c|c|c|c|c|c|c|}
\hline \multirow[t]{2}{*}{ Alt. } & \multicolumn{2}{|c|}{$500-1000$} & \multicolumn{2}{|c|}{$1000 \stackrel{\text { II }}{-} 1500$} & \multicolumn{2}{|c|}{$\begin{array}{c}\text { III } \\
\text { above } 1500\end{array}$} & \multirow[t]{2}{*}{$\begin{array}{l}\text { Significant } \\
\text { differences }\end{array}$} \\
\hline & $\mathrm{N}$ & $\bar{x} \pm \mathrm{SD}$ & $\mathrm{N}$ & $\bar{x} \pm \mathrm{SD}$ & $\mathrm{N}$ & $\bar{x} \pm \mathrm{SD}$ & \\
\hline $\mathrm{CB}$ & (16) & $33.90 \pm 0.73$ & (6) & $33.38 \pm 0.76$ & (12) & $33.83 \pm 0.67$ & \\
\hline $\mathrm{BB}$ & (16) & $16.93 \pm 0.32$ & (5) & $16.68 \pm 0.15$ & (11) & $17.22 \pm 0.31$ & I-III*, II-III** \\
\hline RM & (16) & $10.55 \pm 0.36$ & (6) & $10.35 \pm 0.27$ & (12) & $10.47 \pm 0.28$ & \\
\hline MT & (16) & $13.48 \pm 0.37$ & (6) & $13.37 \pm 0.29$ & (12) & $13.48 \pm 0.31$ & \\
\hline MD & (16) & $23.03 \pm 0.55$ & (6) & $22.62 \pm 0.52$ & (11) & $22.99 \pm 0.68$ & \\
\hline
\end{tabular}

In studying the geographic variability the material from Macedonia was grouped into the following three population groups (Fig. 4): (A) Northwestern (localities: Sar planina Mts., Bistra Mts.), (B) Central (localities: Pletvar, Derven, Prilep, Topolčani), (C) Southern (localities: Mogila, Magarevo, Galičica Mts., Struga, Vratište, Resen).

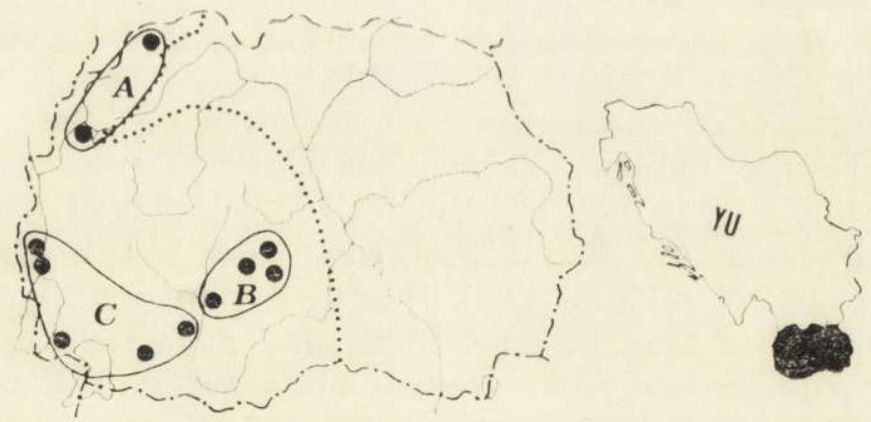

Fig. 4. Geographic position of three groups of populations of Talpa romana stankovici from Macedonia. The concrete localities are marked with closed circles. Dotted line shows the eastern border of Talpa romana stankovici distribution area in Macedonia. Population groups: A - Northwestern, B - Central, D - Southern. See the text for further explanation. 
Four measurements out of five are affected by geographic interpopulation variability ( $\mathrm{CB}, \mathrm{BB}, \mathrm{RM}, \mathrm{MT})$. The northwestern group is significantly greater in longitudinal measurements (CB, MT, RM) than the central one and the southern group of populations reveals a greater RM than the central one. The central group has the smallest $\mathrm{BB}$ and RM (Table 3).

Table 3

Variation in skull measurements in males of Talpa romana stankovici from three different population groups from Macedonia. The designations of the populations are the same as in Figure $4 .{ }^{*} p<.05,{ }^{* *} p<.01$.

\begin{tabular}{|c|c|c|c|c|c|c|c|}
\hline \multirow[t]{2}{*}{ Pop. } & \multicolumn{2}{|c|}{$\frac{\mathrm{A}}{\text { Northwestern }}$} & \multicolumn{2}{|r|}{$\begin{array}{c}\text { B } \\
\text { Central }\end{array}$} & \multicolumn{2}{|c|}{$\begin{array}{c}\text { C } \\
\text { Southern }\end{array}$} & \multirow[t]{2}{*}{$\begin{array}{l}\text { Significant } \\
\text { differences }\end{array}$} \\
\hline & $\mathrm{N}$ & $\bar{x} \pm \mathrm{SD}$ & $\mathrm{N}$ & $\bar{x} \pm \mathrm{SD}$ & $\mathrm{N}$ & $\bar{x} \pm \mathrm{SD}$ & \\
\hline CB & (7) & $34.24 \pm 0.52$ & (8) & $33.44 \pm 0.82$ & (18) & $33.76 \pm 0.72$ & A-B $*$ \\
\hline $\mathrm{BB}$ & (7) & $17.41 \pm 0.19$ & (8) & $16.66 \pm 0.21$ & (17) & $16.97 \pm 0.26$ & $\mathrm{~A}-\mathrm{B}^{* *}, \mathrm{~A}-\mathrm{C}^{* *}, \mathrm{~B}-\mathrm{C}^{* *}$ \\
\hline RM & (7) & $10.59 \pm 0.21$ & (8) & $10.28 \pm 0.32$ & (18) & $10.57 \pm 0.31$ & $\mathrm{~A}-\mathrm{B}^{* *}, \mathrm{~B}-\mathrm{C}^{* *}$ \\
\hline MT & (7) & $13.63 \pm 0.28$ & (8) & $13.26 \pm 0.35$ & (18) & $13.48 \pm 0.32$ & $\mathrm{~A}-\mathrm{B}^{*}$ \\
\hline MD & (6) & $23.33 \pm 0.69$ & (8) & $22.58 \pm 0.62$ & (18) & $23.01 \pm 0.47$ & \\
\hline
\end{tabular}

The northwestern group of populations significantly differs from the southern only in one and from the central in four measurements. The central and the southern group significantly differ in two characters. It means that the greatest differences exist between the northwestern and the central group of populations and the smallest between the northwestern and the southern group of populations. The central group of populations reveals the greatest number of morphological pecularities.

\section{DISCUSSION}

In three Central European populations of Talpa europaea (data according to Stein, 1950) the $\mathrm{CB}$ of males exceeds that of females by 5 to $6 \%$ on an average (by $3 \%$ in T.r.s.), whereas in weight the males are heavier by 26 to $33 \%$ ( $21 \%$ in T.r.s.). Thus in T. europaea sex dimorphism is more pronounced than in T.r.s. In another mole from western Macedonia, i.e. Talpa caeca beaucournui Grulich, 1971, sex dimorphism is expressed as weakly as in T.r.s. The males of T. caeca beaucournui from Pelister Mts. are by $13 \%$ heavier in weight than the females; in the external measurements sex dimorphism varies between 1.01 (HF) and 1.13 (TL) while in the skull measurements between 1.01 (IC, RM) and 1.03 ( $\mathrm{CB}, \mathrm{RC}$; data according to Grulich, 1971). Sex dimorphism is the least pronounced in two mole species living on the border of the genus 
area where the limiting ecological conditions are more outstanding (above all drought which is present during the summer also in mountains).

In western Macedonia at least two and exceptionally even three mole species live sympatrically. T.r.s. and Talpa caeca are quite often found also syntopically (Petrov, 1971). A more pronounced sex dimorphism of these two species would increase the interspecific competition for the larger males of T. caeca would overlap with smaller females of T.r.s. The decrease in sex dimorphism of these two sympatric moles thus represents a phenomenon known as character displacement resulting from niche displacement. Wherever in the Balcan Peninsula two species of moles live sympatrically, a marked difference can be noticed in their size. The small T. caeca can coexist with the large T.r.s. or T. europaea, whereas the latter two, equal in size, never live sympatrically. In Macedonia, for instance, in one case only the populations of T.r.s. and T. europaea come into direct contact with each other (Petrov, 1971). The physically largest populations of $T$. caeca can be found in Yugoslavia in the areas where they do not compete with other mole species (e.g. southern Montenegro; Petrov, 1974). Therefore, the difference in the body size seems to be important factor making possible the syntopic occurrence of two mole species. An increased sex dimorphism in Talpa europaea may result from the absence of congeneric competitors. In this connection it is indispensable to study also the regional variability of sex dimorphism of $T$. europaea in the areas where it lives sympatrically with T. caeca.

Sex dimorphism is obvious also in the correlation structure of skull dimensions. In females the correlation coefficients are gathered, on one side, in a large group of dependent pleiads, and on the other in a large and elongated group of independent pleiads. In males the variability of correlation coefficients is much smaller. In the period of rapid growth, i.e. in young mammals, the skull dimensions are characterized by higher values of correlation coefficients (Buchalczyk \& Ruprecht, 1977; Cabon-Raczyńska, 1964; Kobryńczuk \& Roskosz, 1980; Ruprecht, 1974, 1984). The tendency of a synchronous growth of the skull is preserved in adult males of T.r.s. to a considerably larger extent than in females. In the latter individual differences seem to prevail over isometric growth. It is quite possible that certain regions of the skull with a low correlation with other measurements (above all VL and RC) form themselves earlier in the ontogenetic development. In this way Yegorov (1979; according to Ruprecht, 1984) explains the low correlation of the postorbital breadth with other measurements of the skull in mink.

The coefficients of variation of cranial measurements in T.r.s. from western Macedonia have low values, not exceeding $4 \%$. In mammals, the 
coefficients of variation of linear measurements usually amount to $4-10 \%$ (Mayr, 1969). Irrespectively of such a slight skull variability, significant interpopulation differences exist, showing that the entire population of T.r.s. of Macedonia is morphologically not homogeneous. Altitude has a very weak influence upon the interpopulation variability. The only character (BB) differing in dependence upon altitude reveals no regularity in this respect. In $T$. europaea the size normally decrease with the increasing altitude (Grulich, 1969; Martino, 1930; Stein, 1950). In T.r.s. from Macedonia it is constant irrespectively of the height zone. Scarce data from Thessaly (Felten \& Storch, 1965) point to the existance of smaller T. romana in the lowlands of Greece. Such a decrease of size in dependence upon lowering altitude in $T$. romana was explained as due to a more pronounced dryness of lower regions. It was presumed that in the Mediterranean size depends on humidity as a basic ecologic factor of the environment (Todorović, 1967; Witte, 1964). The finding of small moles with the karyotype of T. romana at Ulcinj, Montenegro (Todorovic et al., 1972) at the altitude of about $5 \mathrm{~m}$ a.s.l. seems to corroborate this presumption. The taxonomic position of this population has not been clearly defined however.

The decennial average $(1971-1980)$ of the humidity of the air (taken as an indicator of the humidity of the environment) of some Macedonian localities is as follows: Sar planina Mts., Popova Sapka (alt. $1750 \mathrm{~m}$ ) 70.1\%; Mavrovi Hanovi $(1240 \mathrm{~m}) 72.9 \%$; Kruševo $(1230 \mathrm{~m}) 74.7 \%$ and Prilep $(673 \mathrm{~m}) 67.8 \%$. We can see that the yearly average reveals no outstanding differences connected with the altitude. In the same period the average humidity at Ulcinj, Montenegro (alt. $97 \mathrm{~m}$ ) amounted to $66.3 \%$ (data taken from the Annuaire meteorologique de l'Institut hydrometeorologique federal, Beograd). It means that no differences in the average relative humidity of air exist between the Macedonian lowlands (Prilep) and Ulcinj in Montenegro; and yet the former is inhabited by a large population of $T$. romana $(\mathrm{CB} 31.6-35.2)$ and the latter by a distinctly smaller population of $T$. cf. romana (CB 28.7-30.2; according to the material in the Nat. Hist. Museum of Slov.). It should be mentioned that T. europaea, which in Yugoslavia lives in a part of the Mediterranean, reveals a decrease of dimensions in dependence upon an increasing altitude. Though not categorically negating the importance of humidity in the formation of the morphotype of moles (T.r.s. from the central group of populations, lying lowest and in the driest areas, is significantly smaller than the population from the Sar planina Mts.), all the differences cannot simply be ascribed to this single ecological factor. Geographic differences between the groups of populations of T.r.s. from Macedonia are more marked than those between single height 
zones which indicates that the influence of ecological factors should not be overvalued. Thus, the differences between the populations of T. romana from the Balcan Peninsula much more likely result from the independent development in the past (e.g. geographic isolation) and also have a taxonomic significance.

Acknowledgement: Thank are due to Dr. B. Petrov who let me study the material from his collection and contributed critical comments on my manuscript.

\section{REFERENCES}

1. Buchalczyk T. \& Ruprecht A. L., 1977: Skull variability of Mustela putorius Linnaeus, 1758. Acta theriol., 22: 87-120.

2. Caboń-Raczyńska K., 1964: Correlations of skull measurements of Lepus europaeus Pallas, 1778. Acta theriol., 8: 207-216.

3. Capanna E., 1981: Caryotype et morphologie cranienne de Talpa romana Thomas de terra typica. Mammalia, 45: 71-82.

4. Corbet G. B., 1978: The mammals of the Palaearctic region: a taxonomic review. British |Museum (Nat. Hist.): 1-314. Cornell Univ. Press. London and Ithaca.

5. Felten H. \& Storch G., 1965: Insektenfresser und Nagetiere aus N-Griechenland und Jugoslavien. Senck. biol., 46: 341-367.

6. Gromov I. M. \& Baranova G. I., 1981: Katalog mlekopitajuščih SSSR. Pliocen-sovremenost. Nauka: 1-456. Leningrad.

7. Grulich I., 1969: Kritische Populationsanalyse von Talpa europaea L. aus den West-Karpaten (Mammalia). Acta Sc. Nat. Brno, 3 (4): 1-54.

8. Grulich I., 1971: Zur Variabilität von Talpa caeca Savi aus Jugoslawien. Acta Sc. Nat. Brno, 5 (9): 1-47.

9. Gureev A. A., 1979: Fauna SSSR. Mlekopitajuščie, 4(2) Nasekomojadnie (Mammalia, Insectivora). Nauka: 1-501. Leningrad.

10. Kobryńczuk F. \& Roskosz T., 1980: Correlation of skull dimensions in the European bison. Acta theriol., 25: 349-363.

11. Martino V. E., 1930: Zamjetki po ekologiji njekotoryh mlekopitajušcih Jugoslaviji. Zapiski Russ. Nauč. Inst. Belgrad; 2: 53-65.

12. Mayr E., 1969: Principles of systematic zoology. McGraw-Hill: 1-428. New York.

13. Petrov B., 1971: Taxonomy and distribution of moles (genus Talpa, Mammalia) in Macedonia. Acta Mus. Maced. Sci. Nat., 6(107): 1-28.

14. Petrov B., 1974: Einige Fragen der Taxonomie und die Verbreitung der Vertreter der Gattung Talpa (Insectivora, Mammalia) in Jugoslawien. Symposium Theriologicum, 2: 117-124. Academia, Praha.

15. Ruprecht A. L., 1972: Correlation structure of skull dimensions in European Hedgehogs. Acta theriol., 17: 419-442.

16. Ruprecht A. L., 1974: Craniometric variations in Central European populations of Ondatra zibethica (Linnaeus, 1766). Acta theriol., 19: 463-507.

17. Ruprecht A. L., 1984: Correlations of skull measurements in the postembryonic development of the house sparrow Passer domesticus. Acta ornithol., 2(2): $147-158$. 
18. Stein G. H. W., 1950: Grössenvariabilität und Rassenbildung bei Talpa europaea L. Zool. Jahrb. (Syst.), 79: 321-349.

19. Todorović M., 1967: Variability of the mole (Talpa) in Macedonia. Arch. biol. Sci., Beograd, 19: 183-191.

20. Todorović M., Soldatović B. \& Dunderski Z., 1972: Characteristics of the karyotype of the populations of the genus Talpa from Macedonia and Montenegro. Arch. biol. Sci., Beograd, 24: 131-139.

21. Witte G., 1964: Zur Systematik der Insektenfresser des Monte-Gargano-Gebietes (Italien). Bonn. zool. Beitr., 15: 1-35.

Received 2 April 1987, Accepted 16 June 1987.

Boris KRYŠTUFEK

\section{ZMIENNOŚC CZASZKI U KRETA TALPA ROMANA STANKOVICI Z MACEDONII}

Streszczenie

Zbadano ezterdzieści sześć czaszek kreta Talpa romana stankovici V. et E. Martino, 1931 z Macedonii. Wykryto wyraźny dymorfizm płciowy: u samców wszystkie wymiary z wyjątkiem szerokości międzyoczodołowej są większe i charakteryzują się wyższym współczynnikiem zmienności (Tabela 1). Wielkość Talpa romana stankovici nie zależy od wysokości nad poziomem morza (Tabela 2). Trzy badane populacje różnily się między sobą pod względem czterech (z pięciu badanych) cech. Zróżnicowanie między populacjami, pochodzącymi z różnych części Macedonii, było większe niż między próbami z różnych stref wysokości nad poziomem morza (Tabela 3). 